\title{
MEASUREMENT OF BONE DENSITY* BIAS AND VARIATION DUE TO RADIOGRAPHIC AND PHOTOMETRIC TECHNIQUES
}

\author{
BY \\ DONALD MAINLAND $\dagger$ \\ From the Department of Medical Statistics and the Study Group on Rheumatic Diseases, \\ New York University College of Medicine
}

(RECEIVED FOR PUBLICATION MAY 8, 1956)

\section{Conflicting Opinions Regarding Densitometry}

"Bone density is an important and little-investigated variable about which we should like to know more" (American Journal of Physical Anthropology, 1954). Here an anthropologist echoed a nutritionist (Nutrition Reviews, 1952) regarding photoelectric densitometer estimates of $x$-ray opacity expressed as thickness of an aluminium or ivory step-wedge (or bone slabs) exposed on the same film as a living subject's hand or other region. This method has been used to measure bone changes in arthritis (Bywaters, 1948; Engström, Wegstedt, and Welin, 1948; Engström and Welin, 1949) and other diseases (Mortimer, Levene, and Rowe, 1937). Its most extensive development (Brown and Birtley, 1951; Mack, 1950; Mack, Brown, and Trapp, 1949; Mack, O'Brien, Smith, and Bauman, 1939; Mack, Trapp, and Brown, 1950) has culminated in the formation of a Bone Density Centre (Brown, 1953; McFarland, 1954) to which films can be sent for rapid assessment by an elaborate and ingenious equipment, and the description of this technique has been so convincing as to prompt the suggestion that it might take the place of calcium balance analyses (Hoobler, 1950).

Many radiologists and rheumatologists, however, remain unconvinced, chiefly because of the variation produced in films by $x$-raying and processing, and the masking of bone mineral loss by overlying soft tissue (and by internal organic matter). These problems arose in two current studies in this department: a search for age differences in bone density in healthy adults, and a seriatim comparison of densities in rheumatoid arthritics, some treated by

\footnotetext{
* Research supported in Canada by grants to the Dalhousie University Anatomy Department from the John and Mary R. Markle Foundation and the National Research Council of Canada; in New York by the National Institute of Arthritis and Metabolic Diseases, U.S. Public Health Service (PHS Grant No. A-104).

$t$ Address: 550 First Avenue, New York 16, N.Y.
}

cortisone and some by other methods. Experiments to determine the effects of technique ( $x$-raying, processing, and photometry) were conducted on cadaver bones and on ivory wedges used as a substitute for bone to avoid variability due to cancellous structure. Several medical radiologists kindly commented on these experiments as follows:

(1) A study of the causes of variability in films should discuss $x$-ray absorption factors, such as atomic number of absorber, energy of radiation, filtration, and scattering.

(2) The effects of technique factors have been known, in general, for many years. Therefore such an investigation is unnecessary.

(3) Because radiologists' scepticism concerns bone density measurements on living subjects, cadaver bone tests can contribute nothing towards overcoming that scepticism.

Since these opinions are held by workers experienced in bone radiology they deserve consideration by anyone who contemplates using densitometric estimates for either clinical or research purposes.

The masking of mineral loss by soft tissue has been well attested (Ardran, 1951; Lachmann and Whelan, 1936; Shackman and Harrison, 1948). Nevertheless, visual assessments of bone shadows continue to be made because a change in mineral content, if large enough (e.g. 20 per cent. for some bones; Lachmann and Whelan, 1936), causes a change in bone shadow density. To those who distrust the eye, even when it is aided by a "standard bone" exposed with every arthritic's hand (Steven, 1947), densitometry offers a desirable substitute for three reasons:

(1) It is more objective than the eye;

(2) It is more sensitive than the eye;

(3) By expressing bone shadow density as equivalent thickness of a standard substance exposed on the same film, it corrects, to a considerable extent, for interfilm differences in overall density. 
A correction for interfilm differences in soft tissue is made also, usually by subtracting from the bone density a quantity derived from readings of soft tissue thickness and density on a film taken at right angles to the bone density film; but this cannot fully undo the masking effect of soft tissue, and densitometry must be regarded as giving an indirect and perhaps far from accurate, estimate of phenomena inside the bone. A similar statement could, however, be made regarding many quantitative biochemical and physiological methods used in clinical and experimental work, and this is not considered sufficient reason for rejecting a method, for failing to find its inherent technical biases and variability, or for attempting to reduce these defects.

\section{Information Required}

Four basic questions regarding bone densitometry may be posed:

(1) How far does the transformation into wedge thickness compensate for the effects of technique differences?

(2) What controllable factors could cause bias, e.g. a spurious difference between films from the same person on two occasions?

(3) How much bias?

(4) If this bias were eliminated, how much variation would remain?

These questions cannot be answered, even "in general", by the numerous published statements regarding the effects of $x$-raying and processing techniques on direct photometer readings of shadows not transformed into wedge thickness (Kieffer and Seideman, 1946; Mattsson, 1951; Mees, 1954; Morgan and Van Allen, 1949; Wilsey, 1934). Specific answers seem to be available only in reports from which numerical values cannot be transferred to current research on bone because they were obtained on tooth slabs nearly 20 years ago (Hodge, Bale, Warren, and Van Huysen, 1935; Hodge, Van Huysen, and Warren, 1935, 1937, 1938; Hodge, Van Huysen, Wilsey, and Warren, 1936; Hodge and Warren, 1936; Hodge, Wilsey, Van Huysen, and Warren, 1937).

Such a laboratory method cannot be evaluated by discussing $x$-ray physics or by applying the criteria of clinical radiology and, since repeated filming of the same object is necessary, cadaver bones must be used. Each investigator should, of course, test the method in the conditions that will prevail when he uses it; but a statement of some of the chief results obtained in this laboratory* will show what factors should, in any case, be controlled.

\footnotetext{
- A detailed report will be available on request.
}

\section{Materials and Methods}

The objects, on $10 \times 12$-in. no-screen films, were human bones (calcaneus, finger phalanx, distal ends of radius and tibia), aluminium, and ivory step-wedges. Exposure: table-top at $72 \mathrm{in}$. from $1 \cdot 2-\mathrm{mm}$. focal spot of rotating-anode tube; $100 \mathrm{ma}$., $0.3 \mathrm{sec}$, as in concurrent living-subject hand studies. Development without agitation permitted estimation of maximal heterogeneity effects due to products of developing.

Seven factors were tested, each at two levels, some of them purposely differing more than was customary:

(1) Wedge Position.--Vertical (VW) versus Transverse (TW).

(2) Kilovoltage.-High (HK, 65 kv.p.) versus Low (LK, 50 kv.p.), as used for adults' and children's hands respectively.

(3) Film Position in Processing.-The end towards the head of the $x$-ray table was called the "top". Top uppermost in hanger (TU) versus Bottom uppermost (BU).

(4) Speed of Developing.-Quick (QD, 5.5 min. in fluid initially fresh but unreplenished during the developing of 56 pairs of films) versus Slow (SD, 7-8 min. in the same fluid weakened by films of another experiment).

(5) Fixation Time.-Short (SF, 20 min.) versus Long (LF, 2-3 hours).

(6) Washing Time.-Short (SW, 1 hour) versus Long (LW, overnight or 6-8 hours by day).

(7) Drying Method.-Warm (WD, in film-dryer) versus Cool $(\mathrm{CD}$, in the open room).

The design was a simple factorial, widely used in? biology (Finney, 1955), chemistry (Youden, 1951), and industry (Brownlee, 1949), and highly recommendable for testing $x$-ray techniques. To include all possible combinations, $2^{7}=128$ films were used, but to show minimal interfilm variation two films ( $A$ immediately followed by $B$ ) were made for each combination and processed together-a total of 256 films. The films were read between cellulose sheets, 0.01 in. thick on a Photovolt transmission densitometer (photometer models $500 \mathrm{~A}$ and $501 \mathrm{~A})$.

\section{Results}

The figures shown below illustrate what was found on bones, but were obtained on an ivory wedge $(9.93 \mathrm{~mm}$. ivory; mean equivalent aluminium $=$ $4.25 \mathrm{~mm}$. - a density similar to that of several hand bones in life).

The results are abbreviated thus:

"In HK, TW $>$ VW, $3 \cdot 2$ per cent. ( $4 \cdot 3), P<0 \cdot 001$ " indicates that, with the higher kilovoltage, the mean density (in $\mathrm{mm}$. aluminium) with wedges transverse exceeded the mean density with wedges vertical by 3.2 per cent. of the latter. $P$, the probability of such differences occurring by chance, is less than one in a thousand. The figure $4 \cdot 3$ is the upper (95 per cent.) confidence limit for the difference, to 
show that the "true" value of the difference, revealed by a much larger experiment, might have approached 4.3 per cent., but there is a 95 per cent. probability that it would not have exceeded that value.

Wedge Position.-In HK, TW $>$ VW, $3 \cdot 2$ per cent. (4.3); $P<0.001$.

In LK, TW $>$ VW, $1 \cdot 5$ per cent. (2.4); $P<0 \cdot 01$.

Kilovoltage.-In SW, HK $>$ LK, $1 \cdot 1$ per cent. $(2 \cdot 2)$; $P=0.05-0.02$.

In $\mathrm{LW}, \mathrm{LK}>\mathrm{HK}, 0 \cdot 5$ per cent. $(1 \cdot 6) ; P=0 \cdot 4-0 \cdot 3$.

Film Position.-In SF, TU $>$ BU, 2.3 per cent. (3.4); $P<0.001$.

In LF, TU $>$ BU, 0.4 per cent. $(1 \cdot 4) ; P=0 \cdot 6-0 \cdot 5$.

Fixation Time.-In TU, SF $>$ LF, $1 \cdot 0$ per cent. (2.1); $P=0 \cdot 1-0.05$.

In $\mathrm{BU}, \mathrm{LF}>\mathrm{SF}, 0.9$ per cent. $(2 \cdot 0) ; P=0 \cdot 1-0 \cdot 05$.

(For tibia as mm. ivory, in SW, LF $>$ SF, $4 \cdot 4$ per cent. (8.0); $P=0 \cdot 02-0 \cdot 01$.)

Washing Time.-In HK, SW $>\mathrm{LW}, 0.2$ per cent. $(1 \cdot 3)$; $P=0 \cdot 8-0 \cdot 7$.

In $\mathrm{LK}, \mathrm{LW}>\mathrm{SW}, 1 \cdot 5$ per cent. $(2 \cdot 6) ; P<0 \cdot 01$.

Drying Method.-In TU, CD $>$ WD, $1 \cdot 0$ per cent. $(2 \cdot 1)$; $P=0 \cdot 1-0 \cdot 05$.

In $\mathrm{BU}, \mathrm{WD}>\mathrm{CD}, 1 \cdot 7$ per cent. $(2 \cdot 8) ; P<0 \cdot 01$.

The ivory wedge was not measured in terms of aluminium in the slowly developed (SD) series, but in radius and tibia the mean densities were significantly greater in SD than in QD films $(P<0 \cdot 01)$. The QD series (128 films), however, showed no influence of progressively weakening developer on bone density expressed as wedge thickness.

Each of the seven factors, under one or more conditions, had a statistically significant effect $(P<0.05)$, and, although the effect of each factor may seem small, the bias produced by their summation would have considerable practical significance also.

Because of a radiologist's question, it is perhaps desirable to point out that the foregoing figures do not "make a direct statistical comparison of factors, such as kilovoltage and fixation time, that are completely independent", or any other kind of comparison between such factors. The experiment was designed to answer practical questions, such as: "If variation in one factor causes bias, is it possible to avoid rigid control of this factor by standardizing another one at a level where the first factor can fluctuate without causing bias?"

Estimation of residual variation (for the same ivory shadow as above) with all seven factors constant but developer heterogeneous as here, gave the following results:

(1) In random pairs of films, each read once, the greater density estimate would, in about 95 per cent. of pairs, exceed the smaller by less than 6.52 per cent. of the latter.

(2) If there were no densitometer reading variation, this value would be 4.95 per cent. Therefore the actual photometry, conducted by nine strict operating rules (specified in the longer report) needs little improvement.

(3) Expressed in the same terms, minimal interfilm variation (between $A$ and $B$ films), without reading variation, would be $4 \cdot 37$ per cent.

\section{Discussion}

The residual variation is attributable partly to unavoidable fluctuations (e.g. of voltage and the timing mechanism) during exposure, and probably largely to a lack of uniformity in the different parts of the developer. This also is difficult to rectify, except with small films, and it is possible that the 6.52 per cent. variation mentioned above could not be materially reduced.

If, however, an investigator found that he could attain this degree of precision on cadaver material, he would probably feel justified in carrying out further tests on living subjects, as by duplicate films of healthy persons at an interval of several weeks; but he should note that the constancy of the seven factors (as well as milliamperage and exposure time) requires a more rigid procedure than has previously been thought necessary (Brown, 1953). Indeed, it appears doubtful if reliable densitometric results can be obtained unless films are exposed and processed by a research-trained technician under conditions of an investigational laboratory.

\section{Summary}

Measurement of bone shadow density by photoelectric cell, with transformation into equivalent thickness of a standard substance (aluminium, ivory, or bone) exposed on the same film, is a useful objective substitute for visual assessment, even if, owing to the masking effect of soft tissue, it cannot claim to indicate bone mineral changes accurately.

Before densitometry can be used confidently, however, it should be strictly evaluated as a laboratory method; and, although much has been published about the effects exerted on direct photometer readings by technique variation in $x$-raying and processing, it is not known precisely how far these effects are negatived by transformation of bone shadow readings into thickness of a standard substance.

Experiments of the simple two-level factorial type, in which cadaver bone shadows and ivory shadows were expressed as aluminium thickness, revealed that, with time and milliamperage constant, each of the seven factors tested-wedge position, kilo- 
voltage, film position in processing, speed of developing, fixation time, washing time, and drying method (in a warm dryer or in an open room)could introduce bias, e.g. a spurious difference between two films from the same subject.

When these factors were held constant, the residual variation was low enough to justify applying the method to living subjects, but to fulfil the necessary requirements it appears essential that a research-trained technician should work under the conditions of an investigational laboratory.

I am greatly indebted to Dr. Pauline B. Mack for information and encouragement in this research, and for donation of the ivory wedges; to Mrs. R. B. Mainland for the radiography; and to Mrs. H. H. Wertheimer for the densitometry.

\section{REFERENCES}

American Journal of Physical Anthropology (1954). 12, 265.

Ardran, G. M. (1951). Brit. J. Radiol., 24. 107.

Brown, W. N. (1953). "Instructions for Exposing and Developing X-ray Films for Bone Density Evaluation." Pennsylvania State College, $\mathbf{P a}$.

, and Birtley, W. B. (1951). Rev. scient. Instrum., 22, 67.

Brownlee, K. A.' (1949). "Industrial Experimentation.", Chemical Publishing Co., Brooklyn, New York.

Bywaters, E. G. L. (1948). Clin. Sci., 6, 281.

Engström, A., Wegstedt, L., and Welin, S. (1948). Acta radiol. 30,440 .

-, and Welin, S. (1949). Ibid., 31, 483.

Finney, D. J. (1955). "Experimental Design and Its Statistical Basis." University of Chicago Press, Chicago.

Hodge, H. C., Bale, W. F., Warren, S. L., and Van Huysen, G. (1935).

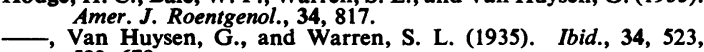
$529,678$.

(1937). Ibid., 37, 529.

$\longrightarrow,-\frac{1}{\longrightarrow}$ (1938). Ibid., 40, 108, 269. Wilsey, R. B., and Warren, S. L. (1936). Ibid., 36, 531.

-, and Warren, S. L. (1936). Ibid., 36, 391.

Wilsey, R. B., Van Huysen, G., and Warren, S. L. (1937). Ibid., 37, 385 .

Hoobler, I. M. (1950). In "Nutrition in Relation to Health and Disease", p. 59. Proc. 1949 Annual Conference. Milbank Memorial Fund, New York.

Kieffer, J., and Seideman, R. M. (1946). Science, 104, 596.

Lachmann, E., and Whelan, M. (1936). Radiology, 26, 165.

Mack, P. B. (1950). In "Nutrition in Relation to Health and Disease", p. 30. Proc. 1949 Annual Conference. Milbank Misease", p. 30. Proc. 1949

-, Brown, W. N., and Trapp, H. D. (1949). Amer. J. Roentgenol., 71,808 .

Science, 89, 467.

-, Trapp, H. D., and Brown, W. N. (1950). In "The Biology of Human Starvation", ed. A. Keys, J. Brožek, A. Henschel, O. Mickelsen, and H. L. Taylor, vol. 2, p. 1081. University of Minnesota Press, Minneapolis.

Mattsson, O. (1951). Acta radiol., 36, 273.

McFarland, W. (1954). Science, 119, 810.

Mees, C. E. K. (1954). "The Theory of the Photographic Process", rev. ed. Macmillan, New York.

Morgan, $\dot{R}$. H., and Van Allen, W. W. (1949). Radiology, 52, 832

Mortimer, H., Levene, G., and Rowe, A. W. (1937). Ibid., 29, 279.

Nutrition Reviews (1952). 10, 119.

Nutrition Reviews (1952), 10, 119. (1948). Brit. J. Surg., 35, 385.

Steven, G. D.' (1947). Annals of the Rheumatic Diseases, 6, 184.

Wilsey, R. B. (1934). Amer. J. Roentgenol., 32, 789.

Youden, W. J. (1951). "Statistical Methods for Chemists." Wiley, New York.

Mesure de la densité osseuse et écarts et variations dus aus techniques radiographiques et photométriques

\section{RÉSUMÉ}

La mesure de la densité de l'ombre osseuse à l'aide d'une cellule photo-électrique, avec transformation en épaisseur équivalente d'une substance standard (aluminium, ivoire ou os) éxposée sur le même cliché, est un suppléant objectif utile de l'examen visuel, même si, en raison de l'effet masquant des tissus mous, elle ne peut prétendre indiquer avec précision les altérations minérales de l'os.

Avant que l'on puisse utiliser la densitométrie avec confiance, il conviendrait qu'elle fût strictement évaluée en tant que méthode de laboratoire et, bien qu'on ait publié beaucoup de choses à propos de l'effet sur la lecture directe au photomètre des variations de technique radiographique et d'impression, on ne sait pas exactement jusqu'à quel point ces effets sont annulés par l'interprétation de l'ombre osseuse en épaisseur d'une substance standard.

Des expériences du type factoriel simple, dans lesquelles des ombres d'os de cadavres et des ombres d'ivoire furent exprimées en épaisseur d'aluminium, révélèrent que, avec le temps et l'intensité constants, chacun des sept facteurs vérifiés: position du coin, voltage, position du cliché durant l'impression, vitesse de développement, temps de fixage, temps de lavage et méthode de séchage (dans un sécheur chaud ou à l'air libre) pouvait introduire un écart, par exemple une différence trompeuse entre deux clichés d'un même sujet.

Quand ces facteurs furent maintenus constants, la variation résiduelle fut assez minime pour justifier l'application de la méthode à des sujets vivants, mais pour remplir les conditions requises il apparaît nécessaire qu'un technicien entrainé à la recherche travaille dans les conditions d'investigation de laboratoire.

\section{Medida de la densidad ósea $y$ desvios y variaciones} debidos a procedimientos radiográficos y fotonsétricos

\section{Sumario}

La medida de la densidad de la sombra ósea con lä ayuda de una célula fotoeléctrica, con transformación en espesor equivalente de una substancia de norma (aluminio, marfil o hueso), expuesta sobre el mismo clisé, es un substituto objetivo útil de la inspección, aún que, en razón del efecto enmascarante de los tejidos blandos, no puede pretender de indicar con precisión las alteraciones minerales del hueso.

Antes de poder emplear la densitometria con confianza, sería preciso averiguar estrictamente su valor como método de laboratorio. Aunque se haya escrito mucho respecto al efecto sobre la lectura fotométrica directa de las variaciones de técnica radiográfica y de revelamiento, no se sabe todavía exactamente hasta que punto estos efectos se ven anulados por la interpretación de la sombra ósea en espesor de una substancia de norma.

Experimentos del tipo factorial simple, en que las sombras de huesos de cadáveres y sombras de marfil fueron exprimidas en espesor de aluminio, revelaron que, con el tiempo y la intensidad eléctrica constantes, cada de los siete factores estudiados: posición del cuño, voltage, posición del clisé durante su manipulación, velocidad del revelamiento, tiempo de la fijación, tiempo de lavar y método de secar (en un secador caliente o al aire libre) podía causar un desvio, por ejemplo una diferencia engañadora entre dos clisés del mismo sujeto.

Al mantener constantes todos estos factores, la variación residual fué suficientemente pequeña para justificar la aplicación del método a sujetos vivos, pero para satisfacer las condiciones requeridas parece necesario que un auxiliar instruido en métodos científicos trabaje en condiciones de investigación de laboratorio. 